NOTE

\title{
Aphanomyces species associated with epizootic ulcerative syndrome (EUS) in the Philippines and red spot disease (RSD) in Australia: preliminary comparative studies
}

\author{
R. B. Callinan ${ }^{1}$, J. O. Paclibare ${ }^{2}$, M. G. Bondad-Reantaso ${ }^{2}$, J. C. Chin ${ }^{3}$, R. P. Gogolewski ${ }^{3}$ \\ ${ }^{1}$ NSW Fisheries, Regional Veterinary Laboratory, Wollongbar, 2477 Australia \\ ${ }^{2}$ Fish Health Section, Bureau of Fisheries and Aquatic Resources, Quezon City, Metro Manila, 1103 Philippines \\ ${ }^{3}$ NSW Agriculture, Elizabeth Macarthur Agricultural Institute, Camden, 2570 Australia
}

\begin{abstract}
Fungi morphologically consistent with class Oomycetes were recovered on primary culture from 20 of 22 ulcers on 21 fish with epizootic ulcerative syndrome (EUS) collected from 5 sites in the Philippines. Eleven primary isolates, and the unifungal cultures derived from them, were identified as Aphanomyces spp.; the remaining 9 primary isolates were lost through contaminant overgrowth. The Aphanomyces isolates were morphologically and culturally indistinguishable from those reported from red spot disease (RSD) in Australia. Comparison of 4 representative Aphanomyces isolates from Australian fish with RSD and 3 representative Aphanomyces isolates from Philippine fish with EUS, using SDS-PAGE (sodium dodecyl sulphate polyacrylamide gel electrophoresis), revealed similar peptide banding profiles, indicative of a single Aphanomyces species. These findings, combined with epizootiological and pathological similarities between EUS and RSD, suggest the 2 syndromes are identical, and that a single Aphanomyces sp. may be the primary infectious cause.
\end{abstract}

KEY WORDS: Aphanomyces - Ulcer - EUS - Philippines · Australia

Since 1980, severe periodic outbreaks of epizootic ulcerative syndrome (EUS) have affected wild and cultured freshwater fishes, as well as wild estuarine fishes, in many countries of South and Southeast Asia (Lilley et al. 1992). Typically affected fish have one or more large dermal ulcers with varying degrees of destruction of underlying tissues, and mortality rates are often high. In the Philippines, periodic outbreaks of EUS have occurred since 1985; many fish genera, including Mugil, Arius and Scatophagus, are affected (Llobrera \& Gacutan 1987, Reantaso 1991).

In eastern and northern Australia, periodic outbreaks of a similar syndrome, known colloquially as 'red spot disease' (RSD), have occurred since 1972 in wild freshwater and estuarine fish (McKenzie \& Hall 1976, Pearce 1990). Affected fish genera include those listed above for the Philippines.

The patterns of spread of both EUS and RSD suggest involvement of one or more primary infectious agents (Rodgers \& Burke 1981, Roberts et al. 1992). Although a number of viruses or bacteria have been recovered inconsistently from fish with EUS (Frerichs et al. 1986. Hedrick et al. 1986, Llobrera \& Gacutan 1987, Roberts et al. 1992, Torres et al. 1992) and RSD (Burke \& Rodgers 1981, Callinan \& Keep 1989, Pearce 1990), no aetiological agent has been conclusively identified for either condition.

Numerous invasive fungal hyphae, morphologically consistent with fungi of the classes Oomycetes or Zygomycetes, are present in histological sections of advanced ulcers from EUS-affected fish (Tonguthai 1985, Bondad-Reantaso et al. 1992, Roberts et al. 1993) and in early and advanced ulcers on RSD-affected fish (McKenzie \& Hall 1976, Callinan et al. 1989, Pearce 1990). Severe necrotising granulomatous dermatitis and myositis are associated with the invasive hyphae. While it is possible that these fungi are opportunists which have invaded ulcers initiated by other agents, the similar fungal morphology and host tissue responses in numerous species of fish with EUS and RSD suggest the fungi may be primary infectious agents in both conditions. Several studies have attempted to identify them. Fraser et al. (1992), using methods which minimise contamination of inocula, isolated an apparently single Aphanomyces sp., an oomycete fungus, from 27 of 28 RSD lesions on 3 species of estuarine fish from widely separated river systems in eastern Australia. These isolates were morphologically and 
culturally very similar, and the authors suggested the putative species was the cause of the typical RSD granulomas. By contrast, Achlya spp. have been recovered from EUS-affected fish in Thailand (Pichyankura \& Bodhalimik 1983) and Sri Lanka (Subasinghe et al. 1990). However, these isolates may have been contaminants; Achlya spp. occur commonly in fresh water in Southeast Asia and, in our experience, the isolation methods used in these studies are likely to result in a high rate of recovery of contaminant fungi. More recently, Roberts et al. (1993) recovered 3 putative Aphanomyces pathogens from EUS-affected striped snakehead Channa striatus in Thailand. These isolates were morphologocially and culturally consistent with those recovered by Fraser et al. (1992), except that the RSD isolates typically had 1 or 2 lateral evacuation tubes on each sporangium, rather than the 4 reported as typical for the Thai EUS isolates.

Materiais and methods. In November and December 1991, EUS-affected fish were collected from 4 widely separated freshwater sites and 1 coastal, fresh-tobrackish water site on Luzon Island, the Philippines; they were then transported live, in local water, to a lab- oratory. Twenty-one fish (14 striped snakehead, 3 mullet Mugil sp., 2 bar-eyed goby Glossogobius giurus, 1 walking catfish Clarias batrachus, and 1 three-spot gourami Trichogaster trichopterus) with typical early to advanced dermal ulcers were killed, and muscle tissue from 22 lesions on these fish was cultured for fungi. The methods of Fraser et al. (1992) were used, with the following modifications: media were inoculated in a Class I microbiological safety cabinet with the airflow system disconnected, and inoculated plates were incubated at 28 to $30^{\circ} \mathrm{C}$. Cultures were examined daily and the methods of Fraser et al. (1992) used to obtain contaminant-free primary fungal cultures and to derive unifungal cultures from them.

Results and discussion. Broad, non-septate, sparsely branching fungal hyphae, indistinguishable from $A p h$ anomyces spp., grew from muscle tissue inocula from 20 of the 22 lesions cultured (Table 1). Of these primary cultures 9 were lost due to overgrowth of bacteria or of fungi morphologically distinct from those present in lesions. The remaining 11 primary cultures, and the unifungal cultures derived from them, were similar in morphology and growth rate, producing flat, slightly

Table 1. Recovery of Aphanomyces isolates from EUS lesions on fish from the Philippines. nfg: no fungal growth. $\bullet$ no data

\begin{tabular}{|c|c|c|c|}
\hline Collection site & Fish species & $\begin{array}{l}\text { Aphanomyces-like growth } \\
\text { on primary culture }\end{array}$ & $\begin{array}{l}\text { Aphanomyces on primary } \\
\text { and unifungal cultures }\end{array}$ \\
\hline \multirow{5}{*}{$\begin{array}{l}\text { Coastal lagoon, Buguey } \\
\text { (Cagayan Province, } \\
\text { Northern Luzon) }\end{array}$} & Mugilsp. & + & + \\
\hline & Mugil sp. & + & + \\
\hline & Mugil sp. & $\mathrm{nfg}$ & - \\
\hline & Glossogobius giuris & + & + \\
\hline & G. giuris & $\mathrm{nfg}$ & $\cdot$ \\
\hline \multirow{5}{*}{$\begin{array}{l}\text { Ricefield, Buguey } \\
\text { (Cagayan Province, } \\
\text { Northern Luzon) }\end{array}$} & Channa striatus & & \\
\hline & Lesion 1 & + & + \\
\hline & Lesion 2 & + & + \\
\hline & C. striatus & + & + \\
\hline & C. striatus & $+_{i} \operatorname{los} t$ & - \\
\hline \multirow{5}{*}{$\begin{array}{l}\text { Pond, Bautista } \\
\text { (Pangasinan Provice, } \\
\text { Central Luzon) }\end{array}$} & C. striatus & + & + \\
\hline & C. striatus & $+:$ lost & - \\
\hline & C. striatus & + ; lost & - \\
\hline & C. striatus & $+;$ lost & - \\
\hline & C. striatus & & \\
\hline $\begin{array}{l}\text { Swamp, Pulinan } \\
\text { (Bulacan Province, } \\
\text { Central Luzon) }\end{array}$ & C. striatus & $+i$ lost & - \\
\hline \multirow{8}{*}{$\begin{array}{l}\text { Laguna Lake } \\
\text { (Laguna Province. } \\
\text { Southern Luzon) }\end{array}$} & C. striatus & + & + \\
\hline & C. striatus & + & + \\
\hline & C. striatus & + & + \\
\hline & C. striatus & $+;$ lost & - \\
\hline & C. striatus & $+i$ lost & - \\
\hline & C. striatus & $+;$ lost & - \\
\hline & Clanias batrachus & + & + \\
\hline & Trichogaster trichopterus & + ilost & - \\
\hline
\end{tabular}


Fig. 1. Aphanomyces sp. recovered from skeletal muscle underlying a dermal ulcer on a striped snakehead Channa striatus from a freshwater pond, Bautista, Pangasinan Province, Central Luzon. (a) Vegetative hyphae (Lugol's iodine; $\times 110$ ); (b) spore cluster (long arrow) and primary spores (short arrows) within sporangium (Lugol's iodine; $\times 225$ )

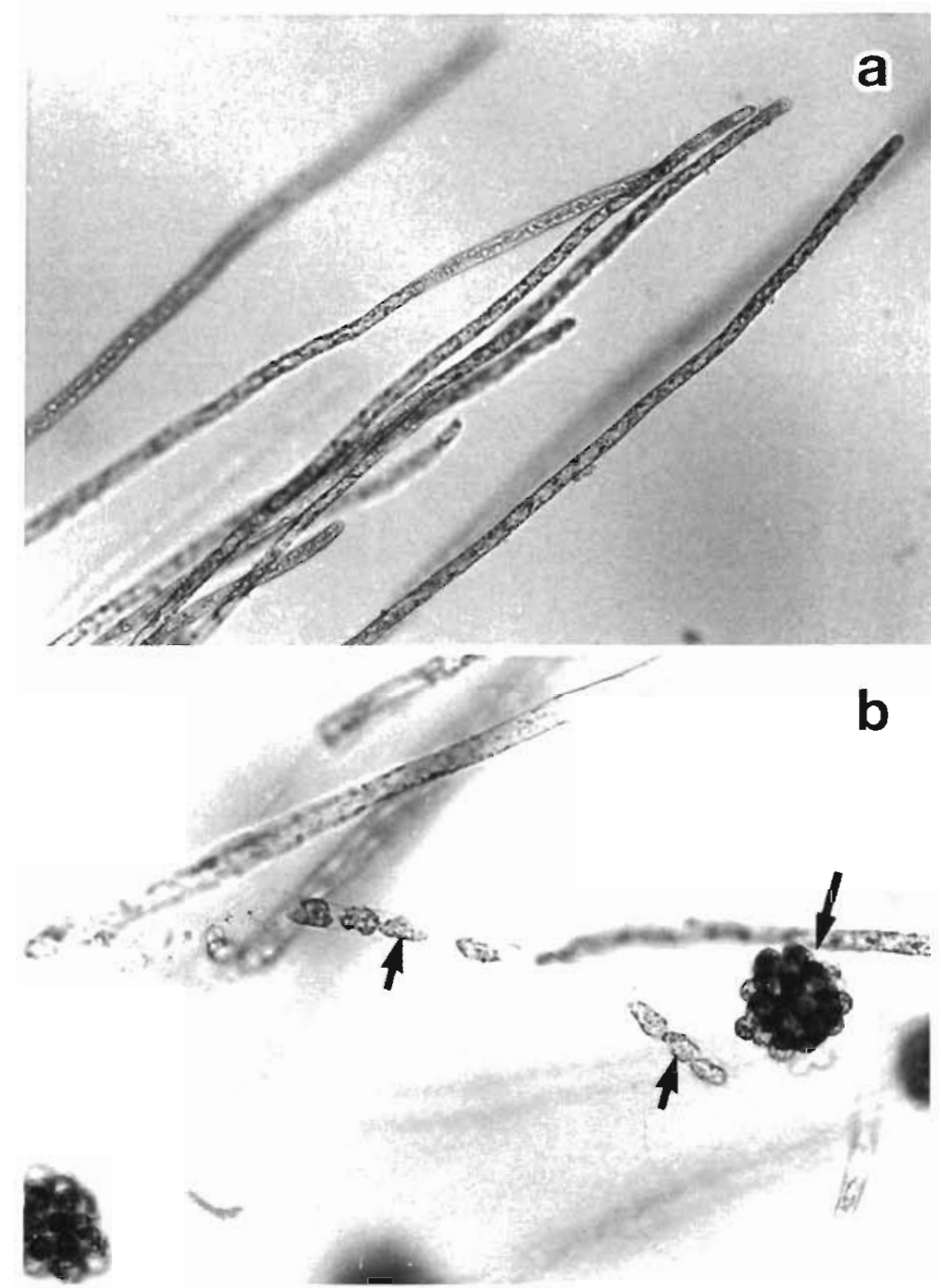

Identification of Aphanomyces spp. is based on differential morphology of oogonia and antheridia (Scott 1961). None of these structures were observed in the present study, none were observed in RSD isolates by Fraser et al. (1992), and none were described for Thai EUS isolates by Roberts et al. (1993). Total protein electrophoresis provides useful, but not definitive, information concerning relationships within and between species of oomycete fungi (Bielenin et al. 1988, Chen et al. 1991). In order to examine possible relationships between isolates, peptide extracts from 4 representative RSD Aphanomyces isolates, 3 representative EUS Aphanomyces isolates, as well as an Aphanomyces laevis type isolate, an Aphanomyces cochloides type isolate, and an Aphanomyces euteiches type isolate were compared electrophoretically (Fig. 3). Fungal mats were derived from GY broth (Griffin 1978, in Dykstra et al. 1986) cultures incubated at $30^{\circ} \mathrm{C}$ in the dark for $15 \mathrm{~d}$. Mats were then rinsed in distilled water, dried, and stored at all 21 fish cultured showed lesions typical of
indistinguishable from those of RSD (Fig. 2). 


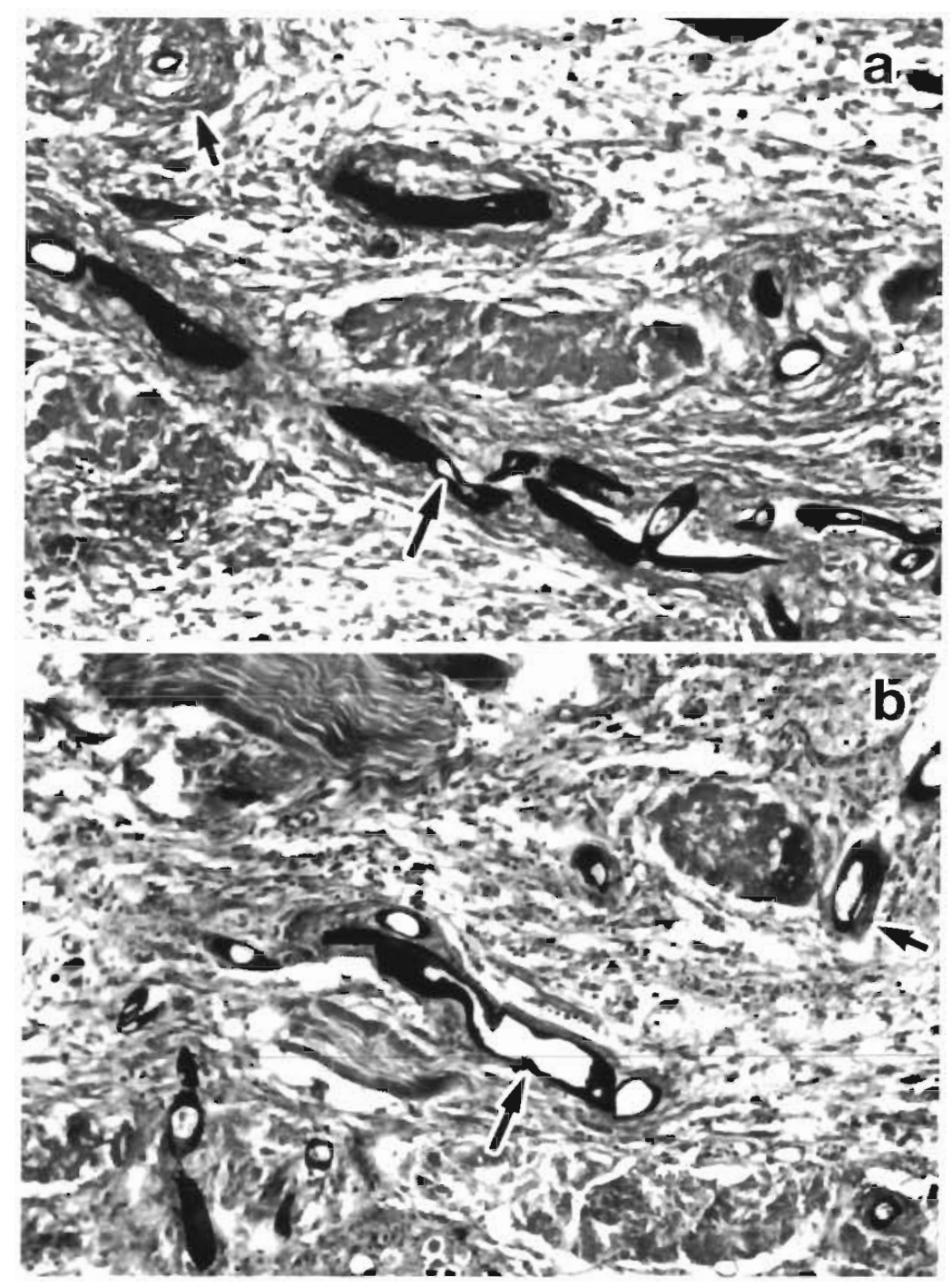

Fig. 2. Skeletal muscle underlying dermal ulcers in EUS-affected fishes from Buguey, Cagayan Province, Northern Luzon. There is severe necrotising myositis and early granuioma formation (short arrows) associated with invading fungal hyphae (long arrows) (Gomori methenamine silver and haematoxylin and eosin; $\times 300$ ). (a) Striped snakehead Channa striatus from a ricefield (b) mullet Mugil sp. from a coastal lagoon $-80^{\circ} \mathrm{C}$. Prior to extraction, frozen fungal mats were placed in liquid nitrogen and ground to a powder with mortar and pestle. $100 \mathrm{mg}$ aliquots of fungi were then extracted by boiling for 5 min in $500 \mu \mathrm{l}$ of reducing mixture $12 \%$ sodium dodecyl sulphate, $5 \% 2$-mercaptoethanol, $10 \%$ glycerol in $62.5 \mathrm{mM}$ Tris-HCl at $\mathrm{pH} 6.8$ ). The mixture was clarified at $5000 \times \mathrm{g}$ and $20 \mu \mathrm{l}$ of the supernatant was loaded into $12 \%$ acrylamide and electrophoresced under reducing conditions according to Laemmli (1970). Peptides resolved by SDS-PAGE were visualised by silver staining (Tsai \& Frasch 1982).

Band similarities or differences between isolates were assessed on the basis of band clusters over specific molecular weight class ranges. On this basis, the banding profiles of isolates from striped snakehead (Bautista), striped snakehead (Laguna), sea mullet (Queensland) and yellowfin bream (Clarence) were very similar over the 14 to $94 \mathrm{kDa}$ range, indicating a close degree of relatedness between these Philippine and Australian strains. The remaining EUS and RSD isolates had similar banding profiles to the above group and to each other, but showed various band cluster differences across this molecular weight range, suggesting they may be less closely related to the above isolates. By contrast, Aphanomyces cochloides, A. laevis, and $A$. euteiches differed greatly from all EUS and RSD isolates and from each other in several band clusters, notably in the 35 to $94 \mathrm{kDa}$ range. The overall similarity in banding profiles between Aphanomyces isolates from RSD and EUS supports the concept that they represent strains within a single species, and this putative species can be clearly differentiated from $A$. cochloides, $A$. laevis and $A$. euteiches by the method used. However, further comparative studies are necessary to validate the hypothesis that a single species is involved.

The high rate of recovery, in the current study, of morphologically and culturally similar Aphanomyces 


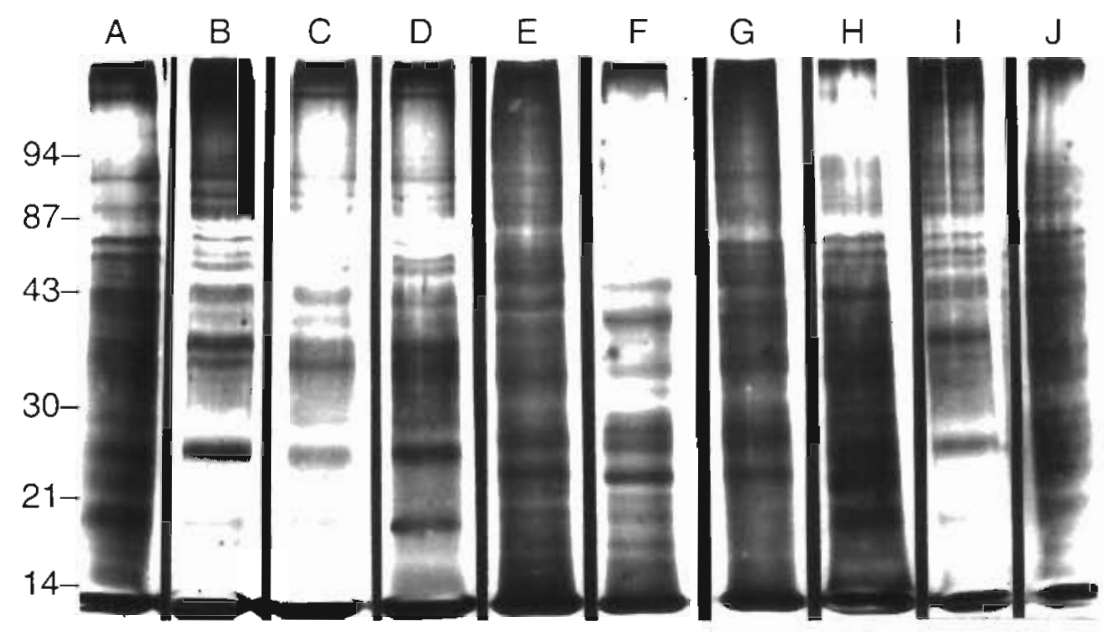

Fig. 3. Aphanomyces spp. Silver-stained SDS-PAGE polypeptide profiles of representative isolates from EUS-affected fish from the Philippines and RSD-affected fish from Australia, and type isolates of A. cochloides, A. laevis, and A. euteiches. Lane A: isolate from mullet Mugil sp., Buguey lagoon, Cagayan Province, Northern Luzon; B: isolate from striped snakehead Channa striatus, Bautista, Pangasinan Province, Central Luzon; C: isolate from striped snakehead Channa striatus, Laguna Lake, Laguna Province, Southern Luzon; D: isolate from sea mullet Mugil cephalus, Saltwater Creek, north Queensland; E: Aphanomyces cochloides (IMI 300493, International Mycological Institute, Kew, UK); F: Aphanomyces laevis (CBS 107.52; Centraalbureau voor Schimmelcultures, Baarn, The Netherlands); G: Aphanomyces euteiches (IMI 300494, International Mycological Institute, Kew, UK); H: isolate from sand whiting Sillago ciliata, Richmond River, New South Wales; I: isolate from yellowfin bream Acanthopagrus australis, Clarence River, NSW; J: isolate from sea mullet Mugil cephalus, Richmond River, NSW. Molecular weight standards are indicated on the left

isolates from EUS-affected fish in the Philippines, combined with the epizootiological and pathological similarities between EUS and RSD, indicates these conditions are identical; we therefore propose the term EUS be used to designate the condition in Australia. The study results also suggest that a single Aphanomyces $\mathrm{sp}$. is associated with EUS in Australia, the Philippines, and elsewhere in Asia, and that it may be the primary infectious cause. In recent decades, this agent could have spread throughout the region, possibly through movements of fish or water, in a manner similar to the spread throughout Europe of Aphanomyces astaci, the cause of crayfish plague (Alderman et al. 1987).

Acknowledgements. We thank Mr R. C. Miranda, Ms F. Siniguian-San Juan, Ms B. Turner, and Ms A. Elston for technical assistance. The study was supported by grants from the Australian Centre for International Agricultural Research and from the Australian Fishing Industry Research and Development Council.

\section{LITERATURE CITED}

Alderman DJ, Polglase JL, Frayling M (1987) Aphanomyces astaci pathogenicity under laboratory and field conditions. J Fish Dis 10:385-393

Bielenin A, Jeffers SN, Wilcox WF, Jones AL (1988) Separation by protein electrophoresis of six species of Phytophthora associated with deciduous fruit crops. Phytopathology $78: 1402-1408$
Bondad-Reantaso MG, Lumanlan SC, Natividad JM, Phillips MJ (1992) Environmental monitoring of the epizootic ulcerative syndrome (EUS) in fish from Munoz, Nueva Ecija, Philippines. In: Shariff M, Subasinghe RP, Arthur JR (eds) Diseases in Asian aquaculture I. Asian Fisheries Society, Manila, p 475-490

Burke J, Rodgers L (1981) Identification of pathogenic bacteria associated with the occurrence of 'red spot' in sea mullet, Mugil cephalus $\mathrm{L}$, in southeastern Queensland. J Fish Dis 4:153-159

Callinan RB, Fraser GC, Virgona JL (1989) Pathology of red spot disease in sea mullet, Mugil cephalus L., from eastern Australia. J Fish Dis 12:467-479

Callinan RB, Keep JA (1989) Bacteriology and parasitology of red spot disease in sea mullet, Mugil cephalus L., from eastern Australia. J Fish Dis 12:349-356

Chen W, Hoy JW, Schneider RW (1991) Comparisons of soluble proteins and isozymes for seven Pythium species and applications of the biochemical data to Pythium systematics. Mycol Res 95:548-555

Dykstra MJ, Noga EJ, Levine JF, Moye DW, Hawkins JH (1986) Characterisation of the Aphanomyces species involved with ulcerative mycosis (UM) in menhaden. Mycologia 78:664-672

Fraser GC, Callinan RB, Calder ML (1992) Aphanomyces species associated with red spot disease, an ulcerative disease of estuarine fish from eastern Australia. J Fish Dis 15: $173-181$

Frerichs GN, Millar SD, Roberts RJ (1986) Ulcerative rhabdovirus in fish in South-east Asia. Nature 322:216

Hedrick RP, Eaton WD, Fryer JL, Groberg WG, Boonyaratpalin $S$ (1986) Characteristics of a birnavirus isolated from cultured sand goby Oxyeleotris marmoratus. Dis aquat Org 1:219-225 
Laemmli UK (1970) Cleavage of structural proteins during assembly of the head of bacteriophage T4. Nature 227: $680-685$

Lilley JH, Phullips MJ, Tonguthai K (1992) A review of epizootic ulcerative syndrome (EUS) in Asia. Aquatic Anımal Health Research Institute and Network of Aquaculture Centres in Asia-Pacific, Bangkok

Llobrera AT, Gacutan RQ (1987) Aeromonas hydrophila associated with ulcerative disease epizootic in Laguna de Bay, Philippines. Aquaculture 67:273-278

Mckenzie RA, Hall WTK (1976) Dermal ulceration of mullet (Mugil cephalus). Aust vet $\mathrm{J} 52: 230-231$

Pearce M (1990) Epizootic ulcerative syndrome technical report, Dec 1987-Sept 1989. Northern Territory Department of Primary Industry and Fisheries, Darwin, Fishery Report No 22

Pichyangkura S. Bodhalimik V (1983) The study of Achlya sp. of fish disease in Ophicephalus striatus. In: Singhaseni P, Ratanapanee $R$, Tangtrongpirus J (eds) The symposium on fresh water fishes epidemic: 1982-1983. Chulalongkorn University, Bangkok. p 197-205

Reantaso MB (1991) EUS in brackish waters of the Philippines? In: Shariff $M$ (ed) Fish Health Section Newsietter 2(1). Asian Fisheries Society, Manila, p 8-9

Roberts RJ, Frerichs GN, Millar SD (1992) Epizootic ulcerative syndrome - the current position. In: Shariff $M$, Subasinghe RP, Arthur JR (eds) Diseases in Asian aquaculture I. Asian Fisheries Society, Manila, p 431-436

Responsible Subject Editor: T Evelyn, Nanaimo, B.C., Canada
Roberts RJ, Willoughby LG, Chinabut S (1993) Mycotic aspects of epizootic ulcerative syndrome (EUS) of Asian fishes. J Fish Dis 16:169-183

Rodgers L, Burke J (1981) Seasonal variation in the prevalence of 'red spot' disease in estuarine fish with particular reference to the sea mullet, Mugil cephalus L. J Fish Dis $4: 297-307$

Scott WW (1961) A monograph of the genus Aphanomyces Technical Bulletin 151, Virginia Agricultural Experiment Station, Blacksburg, VA

Subasinghe RP, Jayasinghe LP, Balasuriya KS, Kulathilake M (1990) Preliminary investigations into the bacterial and fungal pathogens associated with the ulcerative fish disease syndrome in Sri Lanka. In: Hirano R, Hanyu I (eds) The second Asian fisheries forum. Asian Fisheries Society, Manila, p 655-65

Tonguthai K (1985) A preliminary account of ulcerative fish diseases in the Indo-Pacific region (a comprehensive study based on Thai experiences), FAO TCP/RAS/4508. Department of Fisheries, Bangkok

Torres JL, Shariff M, Tajima K (1992) Serological relationships among motile Aeromonas spp associated with healthy and epizootic uicerative syndrome (EUS)-positive fish. In: Shariff $M$, Subasinghe RP, Arthur JR (eds) Diseases in Asian aquaculture I. Asian Fisheries Society, Manila, p 451-460

Tsai CM, Frasch CE (1982) A sensitive silver stain for detecting lipopolysaccharides in polyacrylamide gels. Analyt Biochem 119:115-119

Manuscript first received: May 29, 1992

Revised version accepted: October 25, 1994 